\title{
THE POTENTIAL OF THE SOIL FOR STABILISATION OF ORGANIC CARBON IN SOIL AGGREGATES
}

\author{
ERIKA TOBIAŠOVÁ
}

Slovak University of Agriculture in Nitra

TOBIÁŠOVÁ, E.: The potential of the soil for stabilisation of organic carbon in soil aggregates. Agriculture (Polnohospodárstvo), vol. 61,2015 , no. 2, pp. 50-60.

Carbon stabilisation in soil is the result of interaction between the chemical and physical mechanisms of protection and the dominance of the mechanism depends not only on the long-term constant characteristics of soil but also on the properties, which can be partly influenced by human activities. In this study, the potential of the soil for stabilisation of carbon $\left(\mathrm{P}_{\mathrm{s}}\right)$ in different soil types depending on soil properties was compared. Experiment included six soils (Eutric Fluvisol, Mollic Fluvisol, Haplic Chernozem, Haplic Luvisol, Eutric Cambisol, and Rendzic Leptosol) of different land uses (forest, meadow, urban, and agro-ecosystem) in Slovakia. $\mathrm{P}_{\mathrm{s}}$ was determined with dependence on the ratio of labile and stable fractions of carbon in the soil macro-aggregates. $\mathrm{P}_{\mathrm{s}}$ was in an exponential dependence $(r=0.942 ; P<0.01)$ with production potential of the soil, and the fractions of dry-sieved aggregates larger than $3 \mathrm{~mm}$ play an important role in the first stages of the carbon stabilisation. The suitable parameter, which reflects the changes in carbon stability in the soil is the ratio of the labile carbon and non-labile carbon in the soil macro-aggregates (L/NL). Lower values of L/NL that indicate a higher stability of carbon were determined at a higher $\mathrm{pH}$, at the higher content of carbonates and exchangeable basic cations, and at a higher portion of humic acids free and bound with mobile sesquioxides $\mathrm{R}_{2} \mathrm{O}_{3}$.

Key words: carbon stabilisation, humus substances, labile carbon, non-labile carbon, soil aggregates, soil type

The potential of each soil for the physical stabilisation of soil organic matter depends directly on its properties. Most of them are given by the soil genesis itself, but many of them vary depending on land use and soil management (Debska et al. 2012; Tobiašová et al. 2014). The stability of the soil structure is determined primarily by water-resistant aggregates (Tisdall 1996; Tobiašová 2014), however, in relation to the stabilisation of organic matter, especially in its early stages, are important mainly dry-sieved aggregates, which play a much more important role in the early stages when deciding on the follow up mechanisms for its next stabilisation and are its primary repository. The organic matter is gradually decomposing; the products of metabolism are releasing and the stability is increasing not only in the case of the macro-aggregates, but also in the case of the carbon in them (Oades 1984). This stabilisation is the result of interaction between the chemical and physical mechanisms of organic matter protection (Jastrow \& Six 2006). The dominance of mechanism depends not only on a long-term constant properties such as the particle size distribution (Caravaca et al. 1999; Eustehues et al. 2003; Moni et al. 2010), on a primary content of carbonates or sesquioxides (von Lützow et al. 2006), the overall production potential of soil (Džatko \& Ilavská 2005), but also on the properties that can be partially influenced, such as the soil $\mathrm{pH}$ (Regelink et al. 2015), content of exchangeable basis cations or nature of organic inputs through the land use (Cesare Barbosa et al. 2015; Chrenková et al. 2014). 
After changes in the land use, there occurs not only the reduction of carbon content, but also a change in the ratio of stabile and labile forms of soil organic matter in the ecosystem, and after a period of time, a new balance is created (van Noordwijk et al. 1997). The formation of organo-mineral complexes is a key factor in the stabilisation and sequestration of organic carbon (Baldock \& Skjemstad 2000) and its incorporation into the soil aggregates seems to be a key factor that controls the stock and dynamics of soil organic matter (Oades 1988).

The objectives of this study were as follows: (i) to find out the relationship between the soil type, respectively, production ability and potential of soil for carbon stabilisation, (ii) to determine the parameter, which more characterizes the stability of carbon and reflects changes in more soil properties, and (iii) to specify the soil factors that are in direct relation to this parameter.

\section{MATERIAL AND METHODS}

\section{Characteristics of the territory}

The studied areas are located in different parts of Slovakia (Figure 1). Haplic Chernozem and Mollic Fluvisol come from the locality Horná Králová $\left(48^{\circ} 24^{\prime} \mathrm{N}, 17^{\circ} 92^{\prime} \mathrm{E}\right)$, which are situated on the north- ern border of the Danube Basin. Geological structure is characterised with neogene strata, which consist mainly of claystones, sandstones and andesites, which are covered with younger quaternary rocks that are represented by different fluvial and aeolian sediments (Pristaš et al. 2000). The natural vegetation consists mostly of ash-oak-elm-alder forests, and along the river, there are willow-poplar forests and floodplain forests. In the elevated areas and dunes, xerophilic communities of oak-elm forests are dominant (Korec et al. 1997). Eutric Fluvisol and Haplic Luvisol come from the locality Vráble $\left(48^{\circ} 24^{\prime} \mathrm{N}, 18^{\circ} 31^{\prime} \mathrm{E}\right)$, which is situated in the Danube lowland, in the unit of the Danube plain, concretely in the Nitra upland. Geological structure is characterised with neogene sediments - loess and loess loamy. Neogene bedrock is formed by the lake and brackish sediments (clays, gravels, and sands) (Hók et al. 2001). In the lower parts, oak forests are dominant and in the higher parts, there are beech forests. Rendzic Leptosol comes from the locality Pružina $\left(49^{\circ} 02^{\prime} \mathrm{N}, 18^{\circ} 47^{\prime} \mathrm{E}\right)$, which is situated at the northeastern foot of the hill Strážov, in the valley of the river Pružina. Geological structure is characterised with the core mountains of the outer arc of the Central Western Carpathians. A substantial part of the mountain is composed of nappes with a highly variable resistance of rocks. The core is formed

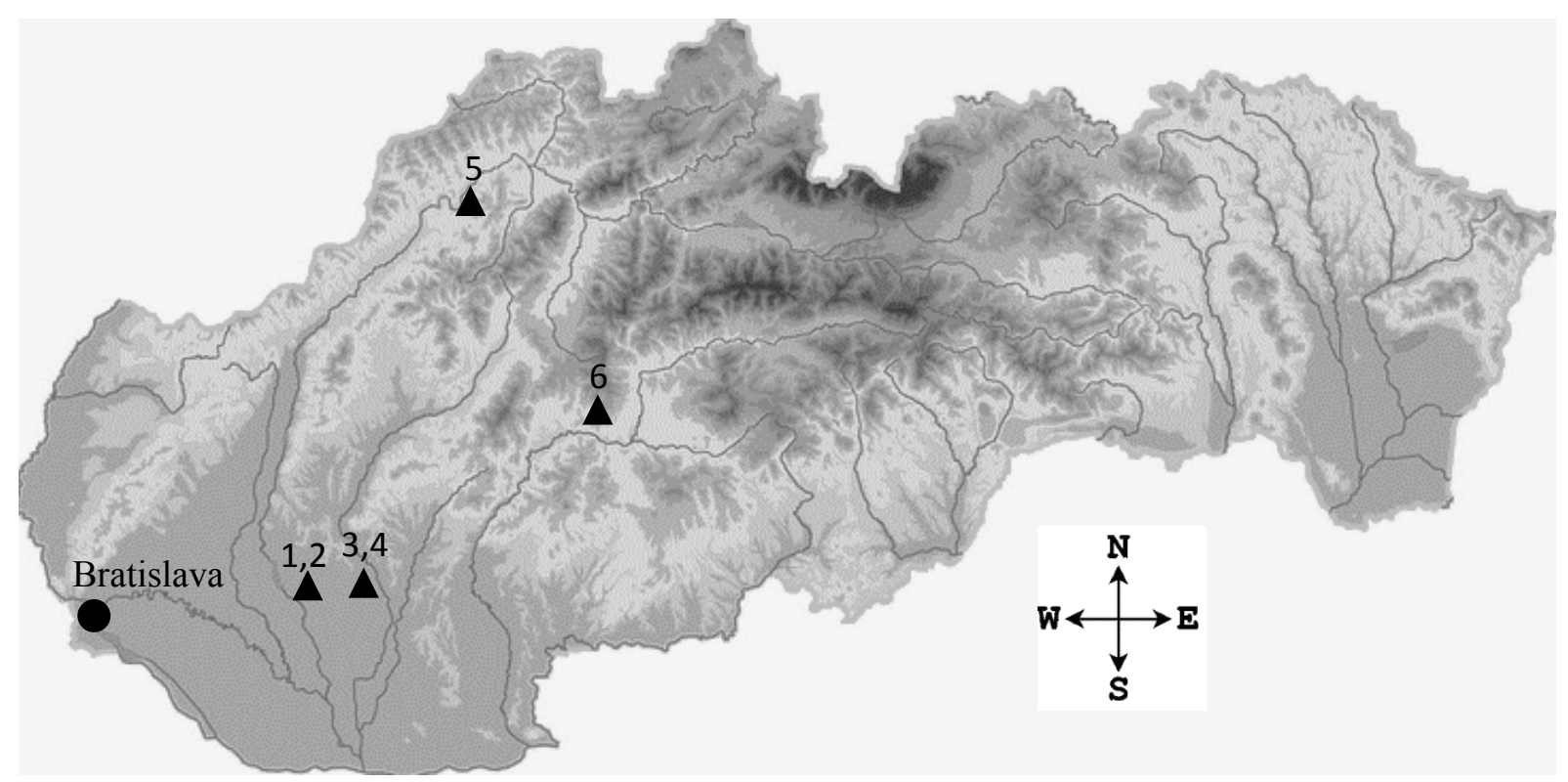

Figure 1. Localities of the soils: 1 - Haplic Chernozem, 2 - Mollic Fluvisol, 3 - Eutric Fluvisol, 4 - Haplic Luvisol, 5 - Rendzic Leptosol, and 6 - Eutric Cambisol 
of the crystalline slates, granites, amphibolites and in the south and southeast, there are mesozoic dolomites, limestones and slates, which are folded and stored in the form of nappe debris (Pristaš et al. 2000). In the forests, beech and oak dominate, with the addition in the higher parts of these forests of fir and higher number of conifers (Korec et al. 1997). Eutric Cambisol comes from the locality Selce $\left(48^{\circ} 76^{\prime} \mathrm{N}, 19^{\circ} 20^{\prime} \mathrm{E}\right)$, which is situated at the slopes of mountain Starohorské vrchy. Geological structure is characterised with the core mountains of the Central Western Carpathians. This part of the mountain is composed of palaeozoic conglomerates, breccias, shales, and sandstones in the south and do- lomites in the east (Pristaš et al. 2000). In the forests, spruce dominates, with the addition in some parts of these forests of deciduous trees (Korec et al. 1997).

\section{Experimental details}

The experiment included four types of ecosystems, which present different land use (forest, meadow, urban, and agro-ecosystems) of six soil types (Eutric Fluvisol, Mollic Fluvisol, Haplic Chernozem, Haplic Luvisol, Eutric Cambisol, and Rendzic Leptosol). These are the soils (Table 1) of lowlands and uplands, which have the largest proportion in Slovakia and are intensively agriculturally used. The forest ecosystems were natural forests

T a b 1 e 1

Basic chemical and physical properties of the soils in different ecosystems

\begin{tabular}{|c|c|c|c|c|c|c|c|}
\hline \multirow{2}{*}{ Soil type } & \multirow{2}{*}{ Ecosystem } & \multirow{2}{*}{$\mathrm{pH}$} & TOC & $\mathrm{CEC}$ & Clay & Silt & Sand \\
\hline & & & {$[\mathrm{g} / \mathrm{kg}]$} & {$[\mathrm{mmol} / \mathrm{kg}]$} & \multicolumn{3}{|c|}{$[\%]$} \\
\hline \multirow{4}{*}{$\begin{array}{l}\text { Haplic } \\
\text { Chernozem }\end{array}$} & $\mathrm{FE}$ & 6.56 & 21.65 & 406.00 & 14.61 & 32.34 & 53.05 \\
\hline & ME & 7.18 & 20.13 & 499.88 & 15.50 & 39.01 & 45.49 \\
\hline & UE & 7.27 & 18.22 & 500.21 & 12.22 & 49.75 & 38.03 \\
\hline & $\mathrm{AE}$ & 7.10 & 17.62 & 412.75 & 17.44 & 50.13 & 32.43 \\
\hline \multirow{4}{*}{$\begin{array}{l}\text { Mollic } \\
\text { Fluvisol }\end{array}$} & $\mathrm{FE}$ & 6.14 & 20.95 & 377.29 & 54.43 & 35.13 & 10.44 \\
\hline & ME & 7.39 & 14.96 & 500.21 & 54.64 & 31.20 & 14.16 \\
\hline & UE & 7.50 & 17.66 & 501.54 & 47.11 & 32.33 & 20.56 \\
\hline & $\mathrm{AE}$ & 6.77 & 11.44 & 347.93 & 46.68 & 36.78 & 16.54 \\
\hline \multirow{4}{*}{$\begin{array}{l}\text { Eutric } \\
\text { Fluvisol }\end{array}$} & FE & 6.33 & 19.85 & 393.20 & 11.17 & 64.55 & 24.28 \\
\hline & ME & 6.75 & 17.11 & 371.49 & 11.49 & 72.46 & 16.05 \\
\hline & UE & 6.78 & 15.11 & 322.78 & 10.74 & 73.65 & 15.61 \\
\hline & $\mathrm{AE}$ & 5.78 & 11.29 & 265.91 & 12.52 & 75.43 & 12.05 \\
\hline \multirow{4}{*}{$\begin{array}{l}\text { Haplic } \\
\text { Luvisol }\end{array}$} & FE & 5.11 & 11.07 & 386.38 & 16.68 & 73.87 & 9.45 \\
\hline & ME & 5.87 & 8.63 & 311.44 & 17.47 & 73.68 & 8.85 \\
\hline & UE & 7.17 & 9.23 & 453.32 & 11.74 & 78.93 & 9.33 \\
\hline & $\mathrm{AE}$ & 6.06 & 10.09 & 320.12 & 14.66 & 69.45 & 15.89 \\
\hline \multirow{4}{*}{$\begin{array}{l}\text { Rendzic } \\
\text { Leptosol }\end{array}$} & $\mathrm{FE}$ & 7.25 & 31.68 & 504.46 & 15.31 & 41.11 & 43.58 \\
\hline & ME & 7.36 & 17.65 & 504.04 & 19.41 & 37.18 & 43.41 \\
\hline & UE & 7.26 & 11.58 & 503.21 & 18.50 & 40.08 & 41.42 \\
\hline & $\mathrm{AE}$ & 7.04 & 13.12 & 442.65 & 15.53 & 50.48 & 33.99 \\
\hline \multirow{4}{*}{$\begin{array}{l}\text { Eutric } \\
\text { Cambisol }\end{array}$} & $\mathrm{FE}$ & 5.63 & 22.30 & 150.96 & 8.50 & 49.49 & 42.01 \\
\hline & $\mathrm{ME}$ & 6.87 & 18.43 & 193.83 & 5.07 & 35.64 & 59.29 \\
\hline & UE & 6.45 & 19.49 & 277.19 & 6.51 & 45.65 & 47.84 \\
\hline & $\mathrm{AE}$ & 6.21 & 18.48 & 205.99 & 6.13 & 41.93 & 51.94 \\
\hline
\end{tabular}

FE - forest ecosystem; ME - meadow ecosystem; UE - urban ecosystem; AE - agro-ecosystem; TOC - total organic carbon; CEC - cation exchangeable capacity 
with human control; the meadow ecosystems were created by man 30 years ago; and the urban ecosystems presented soils of urban landscape (grasses in a town influenced by human activities). The fields in agro-ecosystems were located in different farms under real production conditions. The vegetation in the agro-ecosystem is given by the crop rotations. Dominated crops on the fields were as follows: winter wheat, spring barley, sugar beet, sunflower, corn, soybean (Eutric Fluvisol, Haplic Luvisol); winter wheat, oil rape, alfalfa, sugar beet, sunflower (Mollic Fluvisol, Haplic Chernozem), winter wheat, triticale, corn, alfalfa (Eutric Cambisol), and winter rye, winter wheat triticale, corn, mix of clover and grass (Rendzic Leptosol).

\section{Soil samples and analytical methods used}

The soil samples used to determine the chemical and physical properties were collected in three replicates to depth of $0.30 \mathrm{~m}$, and dried in a constant temperature room of $25 \pm 2^{\circ} \mathrm{C}$. The soil samples for determination of chemical properties were ground. To determine the fractions of soil aggregates, the soil samples were divided by the sieve (dry and wet sieve) to size fractions of the net aggregates (Sarkar \& Haldar 2005). The particle size distribution was determined after dissolution of $\mathrm{CaCO}_{3}$ with $2 \mathrm{~mol} / \mathrm{dm}^{3} \mathrm{HCl}$ and oxidation of the organic matter with $30 \% \mathrm{H}_{2} \mathrm{O}_{2}$. After repeated washing, samples were dispersed using $\mathrm{Na}\left(\mathrm{PO}_{3}\right)_{6}$. Silt, sand, and clay fractions were determined according to the pipette method (van Reeuwijk 2002). In the soil and soil macro-aggregates (dry and wet sieve), the total organic carbon (TOC) by wet combustion (Orlov \& Grišina 1981); the labile carbon $\left(\mathrm{C}_{\mathrm{L}}\right)$ by $\mathrm{KMnO}_{4}$ oxidation (Loginov et al. 1987), were determined and non-labile carbon $\left(\mathrm{C}_{\mathrm{NL}}\right)$ and the lability of carbon $\left(\mathrm{L}_{\mathrm{C}}\right)$ were calculated. In the soil, the next parameters were determined: the fractional composition of humus substances (Ponomarevova \& Plotnikova 1975); the $\mathrm{pH}$ of the soil was potentiometrically measured in a supernatant suspension of a 1:2.5 soil:liquid mixture. The liquid is either $1 \mathrm{~mol} / \mathrm{dm}^{3} \mathrm{KCl}$ $\left(\mathrm{pH}_{\mathrm{KCl}}\right.$ ) (van Reeuwijk 2002); carbonates were determined by volumetric methods (using a simple calcimeter), based on the $\mathrm{CO}_{2}$ evolving after reactions with $\mathrm{HCl}$ (diluted with water in a 1:3 ratio) (Allison $\&$ Moodie 1965). The cation exchangeable capacity (CEC) was determined according to the Pfeffer method (Jackson 2005), and the sum of exchangeable alkaline cations (S) was calculated from the CEC and hydrolytic acidity (van Reeuwijk 2002).

The obtained data were analysed using Statgraphic Plus statistical software. A multifactor ANOVA model was used for individual treatment comparisons at $P<0.05$, with separation of the means by

$\mathrm{T}$ a

Correlations between lability of carbon $\left(\mathrm{L}_{\mathrm{C}}\right)$ in soil aggregates and selected soil properties

\begin{tabular}{|c|c|c|c|c|c|c|c|}
\hline \multicolumn{2}{|c|}{ Macro-aggregates } & $\mathrm{H}$ & $\mathrm{S}$ & $\mathrm{pH} / \mathrm{KCl}$ & $\mathrm{CO}_{3}{ }^{2-}$ & Sand & Silt \\
\hline \multirow{6}{*}{ 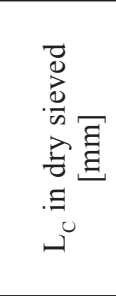 } & $>7$ & $0.46^{++}$ & $-0.50^{+++}$ & $-0.57^{+++}$ & $-0.65^{+++}$ & $-0.50^{+++}$ & $0.52^{+++}$ \\
\hline & $5-7$ & $0.44^{++}$ & $-0.55^{++}$ & $-0.52^{+++}$ & $-0.72^{+++}$ & $-0.57^{+++}$ & $0.61^{+++}$ \\
\hline & $3-5$ & $0.38^{+}$ & $-0.49^{++}$ & $-0.51^{+++}$ & $-0.68^{+++}$ & $-0.58^{+++}$ & $0.62^{+++}$ \\
\hline & $1-3$ & $0.50^{+++}$ & $-0.54^{+++}$ & $-0.57^{+++}$ & $-0.71^{+++}$ & $-0.49^{++}$ & $0.54^{+++}$ \\
\hline & $0.5-1$ & $0.41^{++}$ & $-0.52^{+++}$ & $-0.53^{+++}$ & $-0.72^{+++}$ & $-0.39^{+}$ & $0.41^{++}$ \\
\hline & $0.25-0.5$ & $0.34^{+}$ & $-0.37^{+}$ & $-0.43^{++}$ & $-0.69^{+++}$ & $-0.43^{++}$ & $0.46^{++}$ \\
\hline \multirow{6}{*}{ 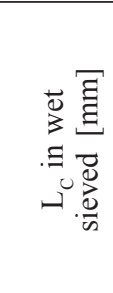 } & $>5$ & $0.45^{++}$ & $-0.56^{+++}$ & $-0.55^{+++}$ & $-0.55^{+++}$ & $-0.47^{++}$ & $0.51^{+++}$ \\
\hline & $3-5$ & $0.37^{+}$ & $-0.49^{++}$ & $-0.48^{++}$ & $-0.62^{+++}$ & $-0.35^{+}$ & $0.40^{++}$ \\
\hline & $2-3$ & $0.37^{+}$ & $-0.43^{++}$ & $0.45^{++}$ & $0.54^{+++}$ & $-0.47^{++}$ & $0.52^{+++}$ \\
\hline & $1-2$ & $0.49^{++}$ & $-0.56^{+++}$ & $-0.52^{+++}$ & $-0.56^{+++}$ & $-0.48^{++}$ & $0.57^{+++}$ \\
\hline & $0.5-1$ & $0.53^{+++}$ & $-0.65^{+++}$ & $-0.60^{+++}$ & $-0.62^{+++}$ & $-0.47^{++}$ & $0.56^{+++}$ \\
\hline & $0.25-0.5$ & $0.33^{+}$ & $-0.45^{++}$ & $-0.43^{++}$ & $-0.62^{+++}$ & $-0.33^{+}$ & $0.40^{++}$ \\
\hline
\end{tabular}

$\mathrm{H}-$ hydrolytic acidity; $\mathrm{S}-$ content of alkaline exchangeable cations; ${ }^{++}{ }^{+} P<0.001 ;{ }^{++} P<0.01 ;{ }^{+} P<0.05$ 
Tukey multiple-range test. Correlation analysis was used to determine the relationships between the chemical properties and parameters of soil structure stability. Significant correlation coefficients were tested at $P<0.05, P<0.01$, and $P<0.001$.

\section{RESULTS AND DISCUSSION}

The obtained results show on a higher importance of the ratio of labile and stabile components rather than their actual contents. The ratio of labile and non-labile carbons, called by Blair (1995) as the lability of carbon $\left(\mathrm{L}_{\mathrm{C}}\right)$, was as in the case of the fractions of dry-sieved macro-aggregates (DSA), even in the fractions of wet-sieved macro-aggregates (WSA), influenced by soil type and was in a direct correlation with more soil properties (Tables 2 and $3)$. In the case of all macro-aggregates fractions, lower values of $\mathrm{L}_{\mathrm{C}}$ were at lower soil acidity, at a higher content of exchangeable alkaline cations and carbonates (Table 2). These soil properties can be to some extent controlled, which increases the potential of the soil for carbon stabilisation in the soil. Humus substances (HS), such as a stabile fraction of organic matter in the soil, had a different influence on the $L_{C}$ values (Table 3). Lower values of $\mathrm{L}_{\mathrm{C}}$ were determined at a higher portion of humic acids, in particular the fraction of humic acids free and bound with mobile sesquioxides $\mathrm{R}_{2} \mathrm{O}_{3}$ ( $\mathrm{HA}$ 1) and vice versa, in the case of fulvic acids free and bound with mobile sesquioxides $\mathrm{R}_{2} \mathrm{O}_{3}$ (FA 1), the values of $\mathrm{L}_{\mathrm{C}}$ were higher. The fraction of aggressive fulvic acids was in a negative correlation with $\mathrm{L}_{C}$. HS are considered an important element in the formation of stabile soil aggregates (Tisdall \& Oades 1982), but their individual fractions participate in the different degree of the stabilisation. According to Tobiašová et al. (2013), the fraction of HA 1 was in a positive correlation with the hydrolytic acidity $(\mathrm{H})$, therefore, higher $\mathrm{H}$ was associated with higher content of HA 1 and a higher value of $\mathrm{L}_{\mathrm{C}}$. Overall, at lower $\mathrm{pH}$, there is more carbon in a labile form (Tobiašová 2010). In the case of FA 1, this correlation was a positive. The reason can be a different solubility of HS. Fulvic acids are soluble in the whole range of $\mathrm{pH}$, but the solubility of humic acids decreases with decreasing of $\mathrm{pH}$ values. Decreasing of $\mathrm{pH}$ values results in the blockade of exchangeable positions by cations of $\mathrm{Al}^{3+}$ and $\mathrm{Fe}^{3+}$ or their

$\mathrm{T}$ a

Correlations between lability of carbon $\left(\mathrm{L}_{\mathrm{C}}\right)$ in soil aggregates and fractions of humus substances

\begin{tabular}{|c|c|c|c|c|c|c|c|c|c|c|}
\hline \multicolumn{2}{|c|}{ Macro-aggregates } & HA 1 & HA 2 & HA 3 & $\Sigma \mathrm{HA}$ & FA 1a & FA 1 & FA 2 & FA 3 & $\Sigma \mathrm{FA}$ \\
\hline \multirow{6}{*}{ 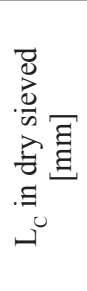 } & $>7$ & $-0.33^{+}$ & n.s. & n.s. & $-0.41^{++}$ & $-0.40^{++}$ & $0.35^{+}$ & n.s. & n.s. & n.s. \\
\hline & $5-7$ & $-0.41^{++}$ & $-0.36^{+}$ & n.s. & $-0.49^{++}$ & $-0.43^{++}$ & $0.47^{++}$ & n.s. & n.s. & n.s. \\
\hline & $3-5$ & $-0.43^{++}$ & n.s. & n.s. & $-0.43^{++}$ & $-0.45^{++}$ & $0.49^{++}$ & n.s. & n.s. & n.s. \\
\hline & $1-3$ & $-0.41^{++}$ & $-0.32^{+}$ & n.s. & $-0.49^{++}$ & $-0.45^{++}$ & $0.51^{+++}$ & n.s. & n.s. & n.s. \\
\hline & $0.5-1$ & $-0.38^{+}$ & n.s. & n.s. & $-0.36^{+}$ & $-0.38^{+}$ & $0.35^{+}$ & n.s. & n.s. & n.s. \\
\hline & $0.25-0.5$ & $-0.45^{++}$ & n.s. & n.s. & $-0.40^{++}$ & $-0.43^{++}$ & $0.38^{+}$ & n.s. & n.s. & n.s. \\
\hline \multirow{6}{*}{ 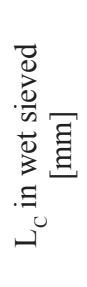 } & $>5$ & $-0.43^{++}$ & $-0.32^{+}$ & n.s. & $-0.49^{++}$ & $-0.34^{+}$ & $0.49^{+++}$ & n.s. & n.s. & n.s. \\
\hline & $3-5$ & $-0.48^{++}$ & n.s. & n.s. & $-0.51^{+++}$ & $-0.49^{++}$ & $0.44^{++}$ & $-0.31^{+}$ & n.s. & n.s. \\
\hline & $2-3$ & $-0.44^{++}$ & $-0.31^{+}$ & n.s. & $-0.50^{+++}$ & $-0.48^{++}$ & $0.47^{++}$ & n.s. & n.s. & n.s. \\
\hline & $1-2$ & $-0.42^{++}$ & $-0.51^{+++}$ & n.s. & $-0.62^{+++}$ & $-0.48^{++}$ & $0.43^{++}$ & n.s. & n.s. & n.s. \\
\hline & $0.5-1$ & $-0.31^{+}$ & $-0.55^{+++}$ & $-0.41^{++}$ & $-0.63^{+++}$ & $-0.34^{+}$ & $0.50^{+++}$ & n.s. & n.s. & n.s. \\
\hline & $0.25-0.5$ & $-0.50^{+++}$ & $-0.41^{++}$ & n.s. & $-0.60^{+++}$ & $-0.42^{++}$ & $0.42^{++}$ & n.s. & n.s. & n.s. \\
\hline
\end{tabular}

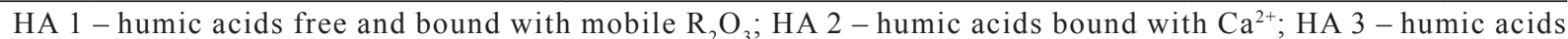
bound with mineral component of soil and stabile $\mathrm{R}_{2} \mathrm{O}_{3}$; $\Sigma \mathrm{HA}$ - sum of humic acids; FA 1a - free aggressive fulvic acids; FA 1 - fulvic acids free and bound with mobile $\mathrm{R}_{2} \mathrm{O}_{3}$; FA 2 - fulvic acids bound with $\mathrm{Ca}^{2+}$; FA 3 - fulvic acids bound with mineral component of soil and stabile $\mathrm{R}_{2} \mathrm{O}_{3}$; $\Sigma$ FA - sum of fulvic acids; ${ }^{++} P<0.001 ;{ }^{++} P<0.01 ;{ }^{+} P<0.05$ 
hydroxides (Brady 1990), especially in the case of therefore, even after their incorporation into aggrefree unprotected humic acids and fulvic acids. HA 1 gates, the lability of carbon does not change and the become more stabile by binding to the sesquioxides correlation between $\mathrm{L}_{\mathrm{C}}$ in aggregates and $\mathrm{HA} 1$ is and by the loss of solubility (Boudot et al. 1989), also a positive. Conversely, the fraction of FA 1 is

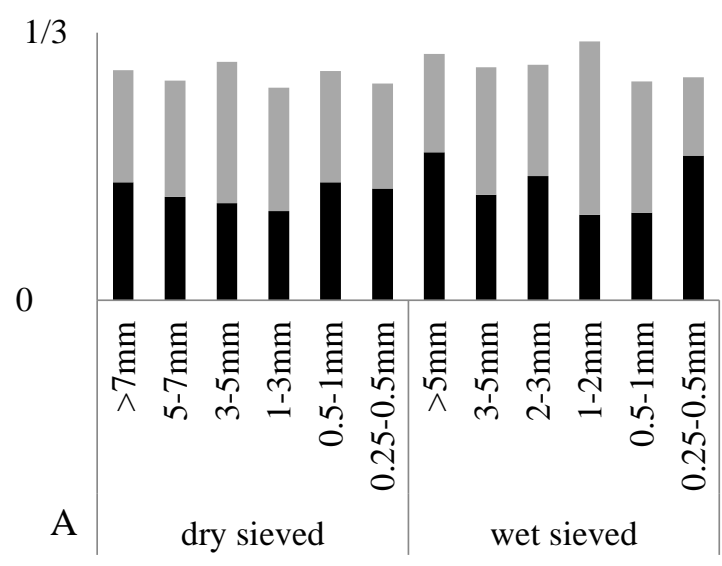

$1 / 3$

0

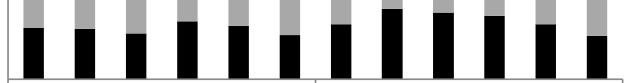

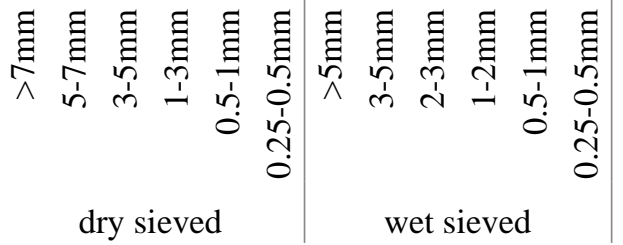

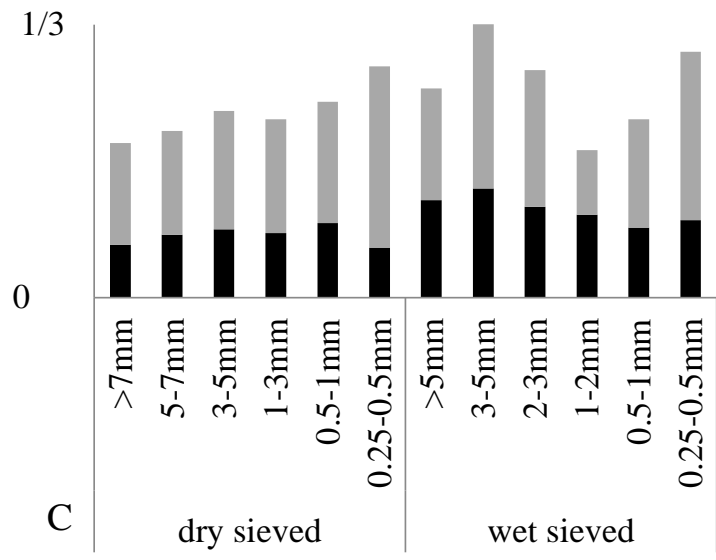

$1 / 3$

0

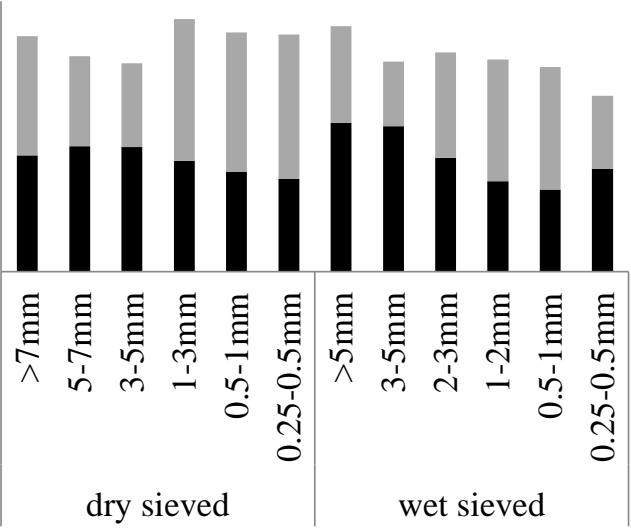

$1 / 3$

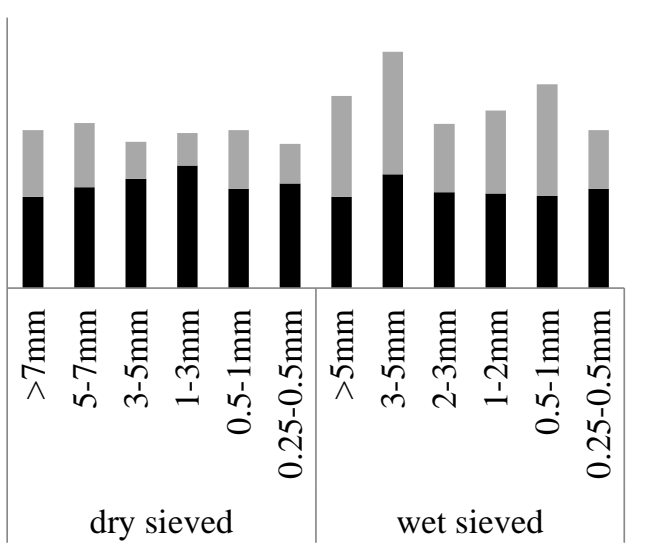

$1 / 3$

0

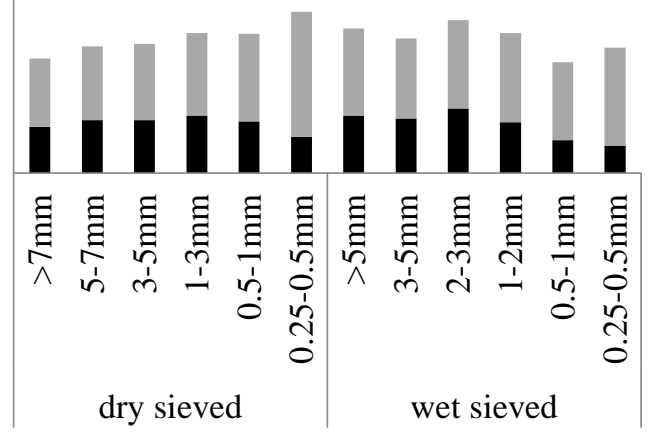

- minimum value of L/NL

- range of variability

Figure 2. The ratio of labile carbon and non-labile carbon (L/NL) in the soil macro-aggregates in: A - Eutric Fluvisol, B - Mollic Fluvisol, C - Haplic Chernozem, D - Haplic Luvisol, E - Eutric Cambisol, F - Rendzic Leptosol 
still in the soluble state at $\mathrm{pH}$ decrease and they subject more easily to degradation, thereby, the portion of labile carbon increases, so the correlation is positive. Dominant charge is negative, similarly as in the case of the mineral colloids, therefore through their incorporation into soil aggregates contribute to increase of the labile component. A correlation between the $\mathrm{L}_{\mathrm{C}}$ and the fraction of aggressive fulvic acids (FA 1a) is negative. The fraction of FA 1a mobilises from the sorption complex alkaline cations and dissolves carbonates that contribute to the carbon stabilisation. The mechanism of stabilisation through the cation bridges (von Lützow et al. 2006) is also often. This strong influence of the mentioned components on carbon stability is confirmed also by a negative correlation of $\mathrm{L}_{\mathrm{C}}$ with the content of exchangeable alkaline cations (S) and carbonates.
Soil $\mathrm{pH}$ and composition of cations in the soil can be partially influenced; the fractional composition of humus substances can be in a short time less influenced, but about the influence of the particle size distribution we can consider in decades or hundreds of years. Silt and clay are, however, one of the basic stabilising agents of organic substances in the soil and are with them in a positive correlation (Bosatta \& Ågren 1997; Tobiašová 2011). Jastrow (1996) observed that clay not only provides protection of organic matter, but also supports the formation of very stabile macro-aggregates. A correlation $\mathrm{L}_{\mathrm{C}}$ with the fraction of clay, however, has not been recorded. This indicates the fact, that not all carbon in the aggregates is stabilised by binding to this fraction, but the stabilisation mechanism can be different; or there is a carbon in the aggregates

$\mathrm{T}$ a $\mathrm{b} 1$ e 4

Statistical evaluation of the lability of carbon $\left(\mathrm{L}_{\mathrm{C}}\right)$ in dry-sieved and wet-sieved macro-aggregates in different soil types

\begin{tabular}{|l|c|c|c|c|c|c|}
\hline \multirow{2}{*}{ Soils } & \multicolumn{3}{|c|}{$\mathrm{L}_{\mathrm{C}}$ in dry sieved $[\mathrm{mm}]$} & \multicolumn{3}{c|}{$\mathrm{L}_{\mathrm{C}}$ in wet sieved [mm] } \\
\cline { 2 - 7 } & $>7$ & $5-7$ & $3-5$ & $>5$ & $3-5$ & $2-3$ \\
\hline Eutric Fluvisol & $0.20^{\mathrm{b}}$ & $0.19^{\mathrm{b}}$ & $0.20^{\mathrm{b}}$ & $0.22^{\mathrm{b}}$ & $0.20^{\mathrm{b}}$ & $0.21^{\mathrm{b}}$ \\
Mollic Fluvisol & $0.12^{\mathrm{ab}}$ & $0.09^{\mathrm{a}}$ & $0.10^{\mathrm{ab}}$ & $0.12^{\mathrm{a}}$ & $0.12^{\mathrm{ab}}$ & $0.11^{\mathrm{ab}}$ \\
Haplic Chernozem & $0.12^{\mathrm{ab}}$ & $0.12^{\mathrm{ab}}$ & $0.13^{\mathrm{ab}}$ & $0.17^{\mathrm{ab}}$ & $0.17^{\mathrm{ab}}$ & $0.17^{\mathrm{ab}}$ \\
Haplic Luvisol & $0.19^{\mathrm{ab}}$ & $0.19^{\mathrm{b}}$ & $0.19^{\mathrm{ab}}$ & $0.21^{\mathrm{b}}$ & $0.19^{\mathrm{ab}}$ & $0.18^{\mathrm{ab}}$ \\
Eutric Cambisol & $0.13^{\mathrm{ab}}$ & $0.15^{\mathrm{ab}}$ & $0.14^{\mathrm{ab}}$ & $0.15^{\mathrm{a}}$ & $0.17^{\mathrm{ab}}$ & $0.15^{\mathrm{ab}}$ \\
Rendzic Leptosol & $0.09^{\mathrm{a}}$ & $0.10^{\mathrm{a}}$ & $0.09^{\mathrm{a}}$ & $0.11^{\mathrm{a}}$ & $0.10^{\mathrm{a}}$ & $0.10^{\mathrm{a}}$ \\
\hline
\end{tabular}

Different letters $(a, b)$ between the factors show statistically significant differences $(P<0.05)-$ Tukey test

$$
\text { T a b } 1 \text { e } 5
$$

Statistical evaluation of the fractions of dry-sieved and wet-sieved macro-aggregates in different soil types

\begin{tabular}{|l|c|c|c|c|c|c|}
\hline \multirow{2}{*}{ Soils } & \multicolumn{3}{|c|}{ Dry sieved [mm] } & \multicolumn{3}{c|}{ Wet sieved [mm] } \\
\cline { 2 - 7 } & $>7$ & $5-7$ & $3-5$ & $>5$ & $3-5$ & $2-3$ \\
\hline Eutric Fluvisol & $27.57^{\mathrm{ab}}$ & $13.10^{\mathrm{a}}$ & $17.92^{\mathrm{ab}}$ & $17.87^{\mathrm{a}}$ & $13.13^{\mathrm{a}}$ & $16.45^{\mathrm{ab}}$ \\
Mollic Fluvisol & $17.27^{\mathrm{ab}}$ & $23.34^{\mathrm{b}}$ & $21.22^{\mathrm{bc}}$ & $5.83^{\mathrm{a}}$ & $10.60^{\mathrm{a}}$ & $13.04^{\mathrm{a}}$ \\
Haplic Chernozem & $17.35^{\mathrm{ab}}$ & $24.05^{\mathrm{b}}$ & $24.24^{\mathrm{c}}$ & $5.75^{\mathrm{a}}$ & $13.36^{\mathrm{a}}$ & $22.26^{\mathrm{b}}$ \\
Haplic Luvisol & $30.77^{\mathrm{b}}$ & $14.50^{\mathrm{a}}$ & $17.95^{\mathrm{ab}}$ & $19.85^{\mathrm{a}}$ & $13.54^{\mathrm{a}}$ & $13.16^{\mathrm{a}}$ \\
Eutric Cambisol & $21.42^{\mathrm{ab}}$ & $10.51^{\mathrm{a}}$ & $13.49^{\mathrm{a}}$ & $11.74^{\mathrm{a}}$ & $11.64^{\mathrm{a}}$ & $18.56^{\mathrm{ab}}$ \\
Rendzic Leptosol & $16.35^{\mathrm{a}}$ & $24.25^{\mathrm{b}}$ & $23.96^{\mathrm{c}}$ & $12.45^{\mathrm{a}}$ & $18.90^{\mathrm{a}}$ & $22.82^{\mathrm{b}}$ \\
\hline
\end{tabular}

Different letters $(\mathrm{a}, \mathrm{b}$, and c) between the factors show statistically significant differences $(P<0.05)-$ Tukey test 


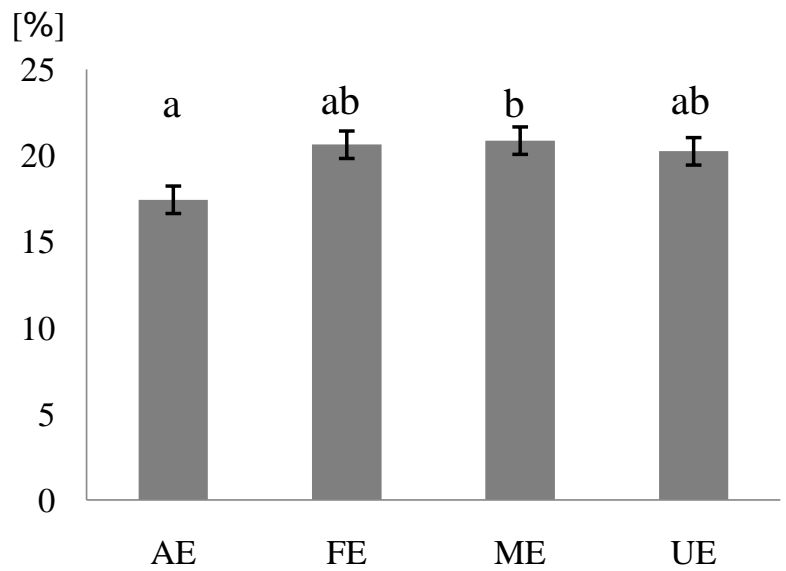

Figure 3. Statistical evaluation of proportion of dry sieved macro-aggregates $(>3 \mathrm{~mm})$

$\mathrm{AE}$ - agro-ecosystem, FE - forest ecosystem, ME - meadow ecosystem, UE - urban ecosystem. Different letters (a, b) between the factors show statistically significant differences $(P<0.05)$ - Tukey test

that has not been meanwhile stabilised. In relation to the parameter of $\mathrm{L}_{\mathrm{C}}$, the contents of sand and silt seem to be more important rather than more often mentioned a fraction of clay (Table 2). $\mathrm{L}_{\mathrm{C}}$ takes into account the existence of other stabilising mechanisms that are a part of the relationship between the carbon and its stability in the soil aggregates. $\mathrm{L}_{\mathrm{C}}$ was in a negative correlation with the fraction of sand. More sand means a higher intensity of the oxidation, which results in the loss of carbon from the soil, but vice versa, the stability of the organic substances increases. Higher stabilisation of humic acids through their increased aromatisation in stronger oxidative conditions is also described by Madari et al. (1998). A correlation of $\mathrm{L}_{\mathrm{C}}$ with the fraction of silt was a positive. Christensen and Sörensen (1985) show that huge amount of the organic matter is bound right on the fraction of the silt and a higher content of the carbon in finer fraction is also a result of high (59\%) recovery of the silt and clay (Christensen 1992). It shows that not all stabile carbon is bound in the aggregates on the fraction of clay. Therefore, the ratio of the labile and non-labile carbons seems to be a more suitable parameter for assessing the stabilisation of organic substances in the aggregates.

More productive soils have a higher potential for stabilisation of the carbon in the aggregates than less productive. The lowest minimum values of $\mathrm{L} / \mathrm{NL}$
$\left(\mathrm{L}_{\mathrm{C}}\right)$ were in the soils with overall a higher quality of the organic matter (Mollic Fluvisol, Haplic Chernozem, and Rendzic Leptosol) (Figure 2) that means in the soils in which the stability of the organic substances is the highest. This potential reflects higher inputs of labile sources in the connection with a higher biodiversity that results in a higher amount of the microbial biomass or plant biomass with richer root exudates, which can be stabilised in the soil aggregates. Moreover, in the case of these soils, the $\mathrm{pH}$ plays an important role.

The most significant differences were recorded in the largest fractions of the macro-aggregates $(>3 \mathrm{~mm})$ (Table 4), and right in the portions of these fractions, the statistically significant differences between the soil types were recorded (Table 5). These are the first potential sink of carbon entering into the soil and already in this stage, it is deciding about his next fate. Higher contents of carbon are in the larger fractions of the macro-aggregates, but this carbon is also subjecting to larger changes, particularly mineralisation (Jastrow 1996; Sohi et al. 2001). Moreover, the portion of DSA of the 3-5 mm size fraction is strongly influenced by land use (Figure 3), which is the next potential for an increasing of carbon stabilisation in the soil.

With respect to the land use, the composition of vegetation has primary influence, which is confirmed by the results of more authors (Barreto et al. 2009; Cantón et al. 2009; Tobiašová 2011). The

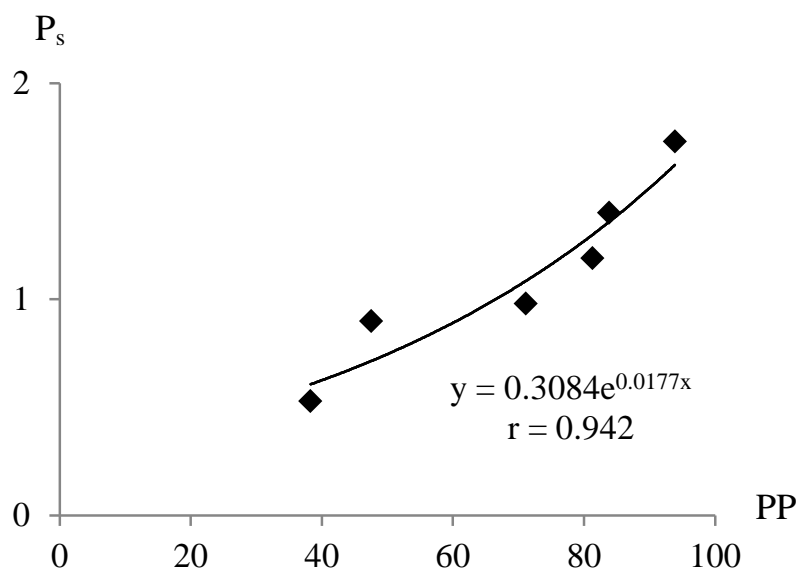

Figure 4. Correlation between production potential (PP) and the potential of soil potential for stabilisation of carbon $\left(\mathrm{P}_{\mathrm{s}}\right)$ 
changes were the most significant just in the DSA, which again show on a higher importance of the carbon content in DSA in the early stages of stabilisation of the organic substances. The total potential of the soil for stabilisation of carbon is the result of the organic substances stabilisation in the all fractions of the DSA and WSA, and is a higher in the Mollic Fluvisol than in Rendzic Leptosol, which is associated with the production capacity of the soil, not only the quality of organic substances. This fact is the best described by the parameter that is the potential of soil for stabilisation of carbon $\left(\mathrm{P}_{\mathrm{s}}\right)$, which includes portions of the labile and non-labile components in relation to the DSA and WSA according to the equation:

$$
P_{s}=\frac{\frac{\Sigma\left(\frac{L_{D}}{N L_{D}}\right)_{1}+\cdots+\left(\frac{L_{D}}{N L_{D}}\right)_{n_{D}}}{n_{D}}}{\frac{\Sigma\left(\frac{L_{W}}{N L_{W}}\right)_{1}+\cdots+\left(\frac{L_{W}}{N L_{W}}\right)_{n W}}{n_{W}}}
$$

where:

$\mathrm{P}_{\mathrm{s}}$ - potential of soil for stabilisation of carbon,

$\mathrm{L}_{\mathrm{D}}$ - labile carbon in DSA [mg/kg],

$\mathrm{NL}_{\mathrm{D}}$ - non-labile carbon in DSA [mg/kg],

$\mathrm{L}_{\mathrm{W}}$ - labile carbon in WSA [mg/kg],

$\mathrm{NL}_{\mathrm{w}}-$ non-labile carbon in WSA [mg/kg],

$n_{D}$ - number of fractions of DSA,

$\mathrm{n}_{\mathrm{w}}-$ number of fractions of WSA.

$\mathrm{P}_{\mathrm{s}}$ is in an exponential dependence with the production potential of soil (Figure 4). The higher the production potential of the soil is, the higher are the values of $\mathrm{P}_{\mathrm{s}}$, which means a higher potential for carbon stabilisation in the soil. This, of course, can be used through the controlling of the mentioned factors, which influence the carbon stability. This means not only through the land use, mainly the crops, but also through the controlling of the soil $\mathrm{pH}$, the contents of exchangeable alkaline cations, and carbonates.

\section{CONCLUSIONS}

The potential of the soil for stabilisation of carbon $\left(\mathrm{P}_{\mathrm{s}}\right)$ is in an exponential dependence with pro- duction potential of the soil, and the fractions of dry-sieved aggregates $>3 \mathrm{~mm}$ play an important role in the first stages of the carbon stabilisation.

The suitable parameter which reflects the changes in carbon stability in the soil is the ratio of labile carbon and non-labile carbon (L/NL) in the soil macro-aggregates, and its lower values indicate a higher stability of carbon.

Lower values of $\mathrm{L} / \mathrm{NL}$ were determined at a higher $\mathrm{pH}$, at higher content of carbonates and exchangeable alkaline cations, and at higher portions of humic acids free and bound with mobile sesquioxides $\mathrm{R}_{2} \mathrm{O}_{3}$.

Acknowledgements. This project was supported by the Scientific Grant Agency of the Ministry of Education of the Slovak Republic and the Slovak Academy of Sciences (No. 1/0124/13 Physical stabilisation of organic matter in soils of different ecosystems).

\section{REFERENCES}

Allison, L.E. - MOODIE, C.D. 1965. Carbonate. In BLACK, C.A. (Ed.). Methods of soil analysis. Part 2. Chemical and microbiological properties. Madison : American Society of Agronomy. pp. 217-218.

BALDOCK, J.A. - SKJEMSTAD, J.O. 2000. Role of the soil matrix and minerals in protecting natural organic materials against biological attack. In Organic Geochemistry, vol. 31, no. 7, pp. 697-710. DOI: 10.1016/ S0146-6380(00)00049-8.

BARRETO, R.C. - MADARI, B.E. - MADDOCK, J.E.L. - PEDRO, J.F. - MACHADO, L.O.A. - TORRES, E. - FRANCHINI, J. - COSTA, A.R. 2009. The impact of soil management on aggregation, carbon stabilization and carbon loss as $\mathrm{CO}_{2}$ in the surface layer of a Rhodic Ferralsol in Southern Brazil. In Agriculture Ecosystem \& Environment, vol. 132, no. 3-4, pp. 243-251. DOI:10.1016/j.agee.2009.04.008.

BLAIR, G.J. - LEFROY, R.D.B. - LISLE, L. 1995. Soil carbon fractions, based on their degree of oxidation, and the development of a carbon management index for agricultural systems. In Australian Journal of Agricultural Research, vol. 46, pp. 1459-1466.

BOSATTA, E. - ÅGREN, G. 1997. Theoretical analyses of soil texture effects on organic matter dynamics. In Soil Biology \& Biochemistry, vol. 29, pp. 1633-1638.

BOUDOT, J.P. - BEL HADJ, B.A. - STEIMAN, R. - SEIGLE-MURANDI, F. 1989. Biodegradation of synthetic organo-metallic complexes of iron and aluminium with selected metal to carbon ratios. In Soil Biology \& Biochemistry, vol. 21, pp. 961-966. 
BRADY, N.C. 1990. The Nature and Properties of Soils. New York : MacMillan Publishing Company. $621 \mathrm{pp}$

CANTÓN,Y. - SOLÉ-BENET, A. - ASENSIO, C. CHAMizO S. - PUIGdefÁBREGAS, J. 2009. Aggregate stability in range sandy loam soils. Relationships with runoff and erosion. In Catena, vol. 77, no. 3, pp. 192-199. DOI:10.1016/j.catena.2008.12.011.

CARAVACA, F. - LAX, A. - ALBALADEJO, J. 1999. Organic matter, nutrient contents and cation exchange capacity in fine fractions from semiarid calcareous soils. In Geoderma, vol. 93, pp. 161-176.

CESARE BARBOSA, G.M. - OLIVEIRA, J.F. - MIYAZAWA, M. - RUIZ, D.B. - FILHO, J.T. 2015. Aggregation and clay dispersion of an oxisol treated with swine and poultry manures. In Soil \& Tillage Research, vol. 146, pp. 279-285. DOI.org/10.1016/j. still.2014.09.022

DĘBSKA, B. - DRĄG, M. -TOBIAŠOVÁ, E. 2012. Effect of post-harvest residue of maize, rapeseed, and sunflower on humic acids properties in various soils. In Polish Journal of Environmental Studies, vol. 21, pp. 603-613.

DŽATKO, M. - ILAVSKÁ, B. 2005.Využívanie výsledkov hodnotenia pôd a územia pre projektovanie pozemkových úprav a ochranu pol'nohospodárskej pôdy: metodická príručka [The using of the results of evaluation of the soils and territories for the design of land consolidation and protection of agricultural soil: Methodological guide]. Bratislava : VÚPOP. 44 pp. ISBN 80-89128-23-8.

EUSTEHUES, K. - RUMPEL, C. - KLEBER, M. KÖGEL-KNABER, I. 2003. Stabilisation of soil organic matter by interactions with minerals revealed by mineral dissolution and oxidative degradation. In $\mathrm{Or}$ ganic Geochemistry, vol. 34, no. 12, pp. 1591-1600. DOI: 10.1016/j.orggeochem.2003.08.007.

HÓK, J. - KAHAN, Š. - AUBRECHT R. 2001. Geológia Slovenska [Geology of Slovakia]. Bratislava : Comenius University. 48 pp. ISBN 80-223-1592-3.

CHRENKOVÁ, K. - MATAIX-SOLERA, J. - DLAPA, P. - ARCENEGUI, V. 2014. Long-term changes in soil aggregation comparing forest and agricultural land use in different Mediterranean soil types. In Geoder$m a$, vol. 235-236, pp. 290-299. DOI.org/10.1016/j. geoderma.2014.07.025.

CHRISTENSEN, B.T. - SÖRENSEN, L.H. 1985. The distribution of native and labelled carbon between soil particle size fractions isolated from long-term incubation experiments. In Journal of Soil Science, vol. 36, pp. 219-229.

CHRISTENSEN, B.T.1992. Physical fractionation of soil and organic matter in primary particle size and density separates. In STEWART B.A. (Ed.) Advances in Soil Science. Berlin Heidelberg New York : SpringerVerlag, pp. 1-90.

JACKSON, M.L. 2005. Soil chemical analysis. Advanced course. A manual of methods useful for instruction and research in soil chemistry, physical chemistry of soil, soil fertility and soil genesis. Madison: University of Wisconsin-Madison Libraries. $930 \mathrm{pp}$.
JASTROW, J.D. - SIX J. 2006. Isotopic investigations into the role of aggregate hierarchy in stabilizing soil organic carbon. In A soil organic matter: Stabilization and carbon sequestration. Abstract of the contribution to the 18th World Congress of Soil Science in Philadelphia. International Union of Soil Sciences.

JASTROW, J.D. 1996. Soil aggregate formation and the accrual of particulate and mineral-associated organic matter. In Soil Biology \& Biochemistry, vol. 28, no. 4, pp. 665-676. DOI: 10.1016/0038-0717(95)00159-X.

KOREC, P. - LAUKO, V. - TOLMÁČI, L. - ZUBRICKÝ, G. - MIČIETOVÁ, E. 1997. Kraje a okresy Slovenska. Nové administratívne členenie [Regions and districts of Slovakia. A new administrative structure]. Bratislava: Q111, $391 \mathrm{pp}$.

LOGINOV, W. - WISNIEWSKI, W. - GONET, S.S. CIESCINSKA, B. 1987. Fractionation of organic carbon based on susceptibility to oxidation. In Polish Journal of Soil Science, vol. 20, pp. 47-52.

MADARI, B. - MICHELI, E. - CZINKOTA, I. - JOHNSTON, C.T. - GRAVEEEL, J.G. 1998. Soil organic mater as indicator of changes in environment. Anthropogenic influences: tillage. In Agrokemia es Talajtan, vol. 47 , pp. $1-4$.

MONI, C. - RUMPEL, C. - VIRTO, I. - CHABBI, A. - CHENU, C. 2010 Relative importance of sorption versus aggregation for organic matter storage in subsoil horizons of two contrasting soils. In European Journal of Soil Science, vol. 61, no. 6, pp. 958-969. DOI: $10.1111 /$ j.1365-2389.2010.01307.x.

OADES, J.M.1984. Soil organic matter and structural stability: mechanisms and implications for management. In Plant \& Soil, vol. 76, pp. 319-337.

OADES, J.M. 1988. The retention of organic matter in soils. In Biogeochemistry, vol. 5, pp. 35-70.

ORLOV, D.S. - GRIŠINA, L.A. 1981. Practical analysis in humus chemistry. Moscow : IMU. 272 pp.

PONOMAREVA, V.V. - PLOTNIKOVA, T.A. 1975. Determination of groups and fractions composition of humus according to method I.V.Ťurin, in modification V.V. Ponomareva and T.A. Plotnikova. In Agrochemical methods of soil analyzes. Moscow : IMU, pp. 47-55.

PRISTAŠ, J. - ELEČKO, M. - MAGLAY, J. - FORDINÁL, K. - ŠIMON, L. - GROSS, P. - POLÁK, M. - HAVRILA, M. - IVANIČKA, J. - HATÁR, J. - VOZÁR, J. - MEllo, J. - NAGY, A. 2000. Geologická mapa Podunajskej nížiny - Nitrianskej pahorkatiny [Geological map of Danube Lowland - Nitra upland.] 1:50000. Bratislava : Ministry of environment of SR and SGI of Dionýz Štúr.

REGELINK, I.C. - STOOF, C.R. - ROUSSEVA, S. WENG, L. - LAIR, G.J. - KRAM, P. - NIKOLAIDIS, N.P. - KERCHEVA, M. - BANWART, S. - COMANS, R.N.J. 2015. Linkages between aggregate formation, porosity and soil chemical properties. In Geoderma, vol. 247-248, pp. 24-37. DOI.org/10.1016/j.geoderma.2015.01.022

SARKAR, D. - HALDAR A. 2005. Physical and Chemical Methods in Soil Analysis. Delhi : New Age International (P) Ltd. 177 pp. ISBN-13: 978-8122427257. 
SOHI, S.P. - MAHIEU, N. - ARAH, J.R.M. - POWLSON, D.S. - MADARI, B. - GAUNT, J.L. 2001. A procedure for isolating soil organic matter fractions for modelling. In Soil Science Society of America Journal, vol. 65, pp. 1121-1128.

TISDALL, J.M. - OADES J.M. 1982. Organic matter and water stable aggregates in soils. In Journal of Soil Science, vol. 33, pp. 141-163.

TISDALL, J.M. 1996. Formation of soil aggregates and accumulation of soil organic matter. In CARTER, M.R. - STEWART, B.A. (Ed.) Structure and Organic Matter Storage in Agricultural Soils. Boca Raton: CRC Press, pp. 57-97.

TOBIAŠOVÁ, E. 2010. Pôdna organická hmota ako indikátor kvality ekosystémov [Soil organic matter as an indicator of ecosystem quality]. Nitra : SUA. $107 \mathrm{pp}$. ISBN 978-80-552-0459-8.

TOBIAŠOVÁ, E. 2011. The effect of organic matter on the structure of soils of different land use. In Soil \& Tillage Research, vol. 114, no. 2, pp. 183-192. DOI: $10.1016 /$ j.still.2011.05.003.

TOBIAŠOVÁ, E. 2014. Stabilita pôdnej organickej hmoty [Stability of soil organic matter]. Nitra : SUA. 92 pp. ISBN 978-80-552-1178-7.

TOBIAŠOVÁ, E. - DĘBSKA, B. - BANACH-SZOTT M. 2013. Kvantita a kvalita pôdnej organickej hmoty a sorpčný komplex pôdy [Quantity and quality of soil organic matter and soil sorption complex]. In Agrochémia, vol. 53, no. 3, pp. 24-26.

TOBIAŠOVÁ, E. -DĘBSKA, B. - BANACH-SZOTT, M 2014. Soil structure and soil organic matter of different ecosystems. In Folia Oecologica, vol. 41, no. 1, pp. 92-99.

VAN NOORDWIJK, M. - CERRI, C. - WOOMER, P.L. - NUGROHO, K. - BERNOUX, M. 1997. Soil carbon dynamics in the humid tropical forest zone. In Geoderma, vol. 79, pp. 187-225.

VAN REEUWIJK, L.P. 2002. Procedures for soil analysis. Wageningen : International Soil Reference and Information Centre. ISBN 90-6672-044-1.

VON LÜTZOW, M. - KÖGEL-KNABNER, I. EKSCHMITT, K. - MATZNER, E. - GUGGENBERGER, G. - MARSCHNER, B. - FLESSA, H. 2006. Stabilization of organic matter in temperate soils: mechanisms and their relevance under different soil conditions: a review. In European Journal of Soil Science, vol. 57, no. 4, pp. 426-445. DOI: 10.1111/j.13652389.2006.00809.x.

Received: March 20,2015 